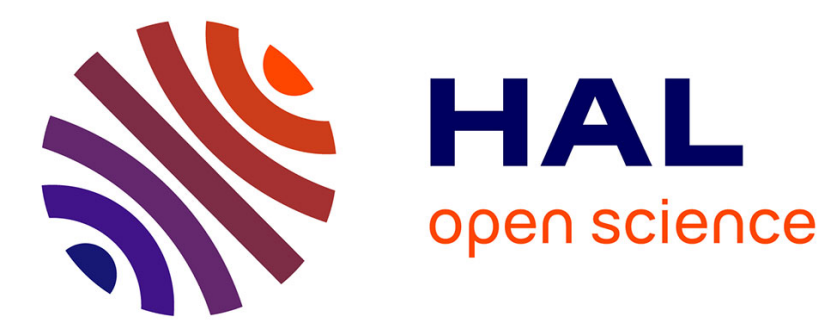

\title{
Siwi addressee agreement and demonstrative typology Lameen Souag
}

\section{To cite this version:}

Lameen Souag. Siwi addressee agreement and demonstrative typology. STUF, 2014, Berber in typological perspective, 67 (1), pp.35-45. 10.1515/stuf-2014-0004 . halshs-01376214

\section{HAL Id: halshs-01376214 https://shs.hal.science/halshs-01376214}

Submitted on 5 May 2021

HAL is a multi-disciplinary open access archive for the deposit and dissemination of scientific research documents, whether they are published or not. The documents may come from teaching and research institutions in France or abroad, or from public or private research centers.
L'archive ouverte pluridisciplinaire HAL, est destinée au dépôt et à la diffusion de documents scientifiques de niveau recherche, publiés ou non, émanant des établissements d'enseignement et de recherche français ou étrangers, des laboratoires publics ou privés. 
Postprint of:

Souag, Lameen. 2014. Siwi addressee agreement and demonstrative typology. In ed. Catherine Taine-Cheikh, STUF - Language Typology and Universals 67:1, Berber in typological perspective, pp. 35-45. DOI: $10.1515 /$ stuf-2014-0004.

\title{
Siwi addressee agreement and demonstrative typology
}

\begin{abstract}
Siwi, a Berber language of Egypt, shows gender / number agreement of medial demonstratives with the addressee. Such phenomena are cross-linguistically very rarely reported, and are not discussed in major surveys of the typology of demonstratives (Diessel 1999; IMAI 2003). However, within person-oriented demonstrative systems, such marking amounts to an iconic representation of addressee anchoring. The pragmatics of Siwi demonstratives thus cast light on the nature of the mapping from person to place that such systems reflect (GREENBERG 1985). Comparative eastern Berber data suggests that demonstrative addressee agreement may be more widespread than the literature reflects.
\end{abstract}

Keywords: Berber, agreement, demonstratives, person-oriented, allocutivity

Lameen Souag: LACITO (CNRS / Univ. Sorbonne Nouvelle), 94801 Villejuif Cedex, France

E-mail: lameen@gmail.com

\section{Introduction}

Typological parameters relevant to the description of demonstrative systems have been the subject of extensive investigation (Diessel 1999; Imai 2003). One of the best-known is distance-oriented vs. person-oriented (for IMAI, addressee-isolated vs. dual-anchor). The latter type, with a proximal 'near speaker' and a medial 'near hearer', has been recognised for over a century (BRUGMANN 1904; ANDERSON \& KeEnan 1985). Such systems amount to a mapping of space with reference to the participants; as GREENBERG (1985:277) put it, "person becomes the model for place as the icon." This would make person markers on the appropriate demonstrative terms iconic. In principle, their incorporation should entail demonstrative agreement with the addressee, producing addressee agreement.

This phenomenon is, in practice, hardly ever reported: addressee agreement is absent from even the most extensive available cross-linguistic typological surveys of demonstrative systems. However, Siwi - a Berber language spoken in western Egypt - is one of the very few languages worldwide to use addressee agreement productively on demonstratives. (To the best of my knowledge, the only other 
exceptions reported are Qur'ānic Arabic and Rāziḥ̄i Arabic; cf. WATSON (2006b:48).) As such, Siwi provides a unique window onto the mechanics of the mapping from person to distance, as well as illustrating a parameter that needs to be taken into account in language documentation.

\section{Demonstratives in Siwi}

\subsection{General description}

Pro/ad-nominal demonstratives in Siwi are inflected for number and gender (masculine/feminine), like $75 \%$ and $45 \%$ respectively of the 85 languages in Diessel (1999: 25); Siwi, however, distinguishes gender only in the singular. Adnominal demonstratives are formed from pronominal ones by adding a prefix $d a$ - (ta- in F.SG); presentatives ("here is...") by prefixing $\gamma^{-}(x-$ in F.SG). In adverbial/locative contexts, where there is no referent with agreement features, the stems are proximal $-a$, medial $-o k$ (etc.), distal $-i h$. Demonstrative adverbs of manner are formed by suffixing these to ams-. Specific location is formed by suffixing them to $g d$ - (also used in Siwi as the pre-pronominal allomorph of "in"); vague location (IMAI 2003), to $s s$ - (cp. $s$ "from"). (Specific location is incompatible with distal -ih, presumably because the distal includes no anchor.)

Siwi has three distances, along with $38 \%$ of the 234 languages sampled in WALS (Diessel 2011). While the difference in form between the $w a$ and waya series below suggests a fourth distance, no difference in reference has been observed, and speakers themselves describe $w a$ as just an "abbreviation" of waya.

Place-holders ("whatchamacallit") use the synchronically distinct series wihin (M.SG, PL) / tihin (F.SG), historically deriving from distals, exemplifying a crosslinguistically common usage (HAYASH \& YoON 2006); these are nouns, and can even be modified by adnominal demonstratives, eg wihin dawok "that whatsit".

So far, this is typologically unexceptional. However, as shown by Table 1 (adapted from Souag 2010), it also features a phenomenon requiring closer attention: the medial term varies in form according to the gender and number of the addressee. 
Table 1: Demonstratives in Siwi

\begin{tabular}{|c|c|c|c|c|c|}
\hline & Proximal & $\begin{array}{l}\text { Medial } \\
\text { (to man) }\end{array}$ & $\begin{array}{l}\text { Medial (to } \\
\text { woman) }\end{array}$ & $\begin{array}{l}\text { Medial (to } \\
\text { group) }\end{array}$ & Distal \\
\hline Pronominal: M.SG & $w a(y a)$ & wok & wom & werwan & wih \\
\hline - F.SG & $t a(y a)$ & tok & tom & terwan & tih \\
\hline - PL & wi(yya) & wiyyok & wiyyom & wiyyerwan & widin \\
\hline Adnominal: M.SG & dawa(ya) & dawok & dawom & dawerwan & dawih \\
\hline- F.SG & $\operatorname{tata}(y a)$ & tatok & tatom & taterwan & tatih \\
\hline - PL & dawi(yya) & dawiyyok & dawiyyom & dawiyyerwan & dawidin \\
\hline Presentative: M.SG & $\gamma w a(y a)$ & jwok & Jwom & Jwerwan & gwih \\
\hline- F.SG & $x t a(y a)$ & xtok & xtom & xterwan & xtih \\
\hline$-\mathrm{PL}$ & zwi(yya) & Jwiyyok & fwiyyom & Jwiyyerwan & Jwidin \\
\hline Locative & $g d a(y a)$ & gdok & gdom & gderwan & - \\
\hline $\begin{array}{l}\text { Approximate } \\
\text { locative }\end{array}$ & $s s a$ & ssok & ssom & sserwan & $\operatorname{ssih}$ \\
\hline Manner adverb & amsa & amsok & amsom & amserwan & amsih \\
\hline
\end{tabular}

\subsection{Addressee agreement}

The agreement of the medial demonstrative with the addressee is illustrated by the following minimal pairs, mostly from a retelling of the story of Joseph:

Standalone medial, referent $=$ M.SG, different addressees:

$\begin{array}{lllllll}\text { yə-mm-as: } & a & \text { waldi... } & \text { wo-k } & \text { xer } & \text { a-zuwwar }\end{array}$ He told him: $\mathrm{O}$ my son that is a great good.

2 yə-ṃm-as $i$ talt-ənnəs: wo-m ge-yə-nfu-yanax

3M-say-3SG.DAT to woman-3sG.GEN: DEM.M-2:F IRR-3M-benefit-1 PL.DAT

He told his wife: this one will benefit us.

3 yə-ṃm-asən: we-rwan aggwid $n$ roḅbi

3M-Say-3PL.DAT: DEM.M-2:PL man GEN God

He told them: this is a man of God.

Modifying medial, referent $=$ F.SG., different addressees: 


\section{4 tasútat ta-tó-k talla múddat-laSmər} palm_tree MOD-DEM.F-2:M 3F.be_at lifetime

That palm tree has been around for ages. (addressing male researcher)

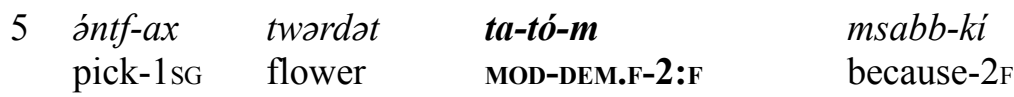

I picked this flower for your (f.) sake.

$6 \quad m m^{w} i$ - - -asín-a $i$ itadəm-ánnəw: say-1sG-3PL.DAT-PRF to people-1sG.GEN
g-úsad
$g$ aliarbíyya
ta-té-rwon
IRR.3M-come
in car
MOD-DEM.F-2:PL

I told my family: he will come in that car.

The suffixes used to mark addressee agreement on the medial demonstrative are closely parallel to the $2^{\text {nd }}$ person prepositional object suffixes: $2 \mathrm{M} . \mathrm{SG}-\partial k, 2 \mathrm{~F} . \mathrm{SG}-\partial m$, 2PL $-w a n$.

The most obvious typological comparison for addressee agreement is verbal allocutivity - a phenomenon best known from Basque (AlBerdi 1995), but also attested in several other languages (ANTONOv 2010). Verbal allocutivity is typically restricted to main clauses rather than subordinate clauses. Addressee agreement, however, occurs irrespective of the level of syntactic embedding, as illustrated by multiply layered possessives:

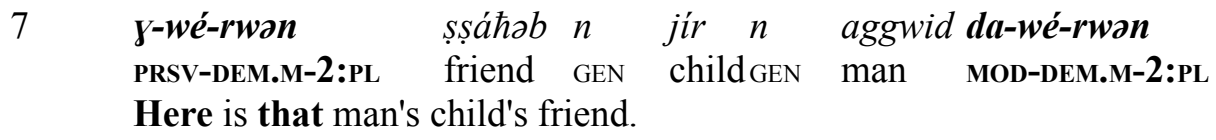

and multiply embedded subordinate clauses:

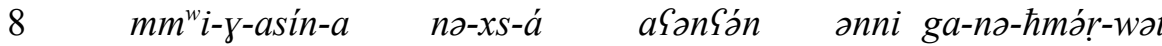
say-1sG-3PL.DAT-PRF 1 PL-want-PFV to_sit_down COMP IRR-1PL-look-PL.IMP

$\begin{array}{llll}\text { mámək } & \text { ga-nattáws-as } & i & a g g^{w} i d \text { da-wé-rwon } \\ \text { how IRR-1PL-help-3SG.DAT to } & \text { man MOD-DEM.M-2:PL }\end{array}$

Addressee agreement must be self-consistent; when the following inconsistent sentence was proposed to him, my consultant reacted "As long as you're saying $g a$ $\check{s}$ - $\gamma$-ak (2M.DAT), you say $d a-w o-k$ [MOD-DEM.M-2:M]": 


\begin{tabular}{|c|c|c|}
\hline $\begin{array}{l}\text { *ga- } \text { - }-\gamma \text { - } a k \\
\text { *IRR-give-1SG-2M.DAT }\end{array}$ & $\begin{array}{l}\text { ssanduq } \\
\text { box }\end{array}$ & $\begin{array}{l}d a-w o ́-m \\
\text { MOD-DEM.M-2:F }\end{array}$ \\
\hline
\end{tabular}

As the following sentence illustrates, there is no such inconsistency between a singular addressee and a plural $2^{\text {nd }}$ person pronoun; after all, an object can equally well simultaneously be close to a whole group and to a single member of it:

10

$\begin{array}{lll}g a-\check{s} \text { - } y \text {-áwan } & \text { ssanduq } & d a-w-o ́ k \\ \text { IRR-give-1SG-2PL.DAT } & \text { box } & \text { MOD-DEM.M-2:M } \\ \text { I will give you that box. } & \end{array}$

\subsection{Usage of the medial}

As we expect from the presence of addressee agreement on the medial term, the Siwi demonstrative system is speaker/addressee-anchored. The nature of this anchoring needs closer examination, since, as well as marking spatial location, but demonstratives serve several other discourse and information structure functions.

The system is most clearly revealed in accessibility contrasts: items only accessible to the speaker use the proximal, ones accessible to the listener use the medial, and ones inaccessible to both the distal. When an item is equally associated with or accessible to the speaker and the addressee, the medial series is preferred. Thus, in the following examples ${ }^{1}$, the speaker was watching a film, while the listener could not see the screen but could hear the sound, yielding the following contrast:

$\mathrm{Ah}$, this is the sound of goats.

$$
\begin{array}{lcc}
\text { tyátt } \quad \text { tá-ta } & \check{s} s ̌ a k l \text {-ánnas } & n \text {-azágru. } \\
\text { goat MOD-DEM.F } & \text { shape-3sG.GEN } & \text { [goat sp.] } \\
\text { This goat looks like a } n \text {-azagru (breed). } &
\end{array}
$$

Most Berber demonstrative systems include separate anaphoric forms for marking old information, eg Kabyle -nni (Меттоuснг 2011). In Siwi, no such form exists; rather, the medial demonstrative is typically used, marking the information as accessible to the listener. For instance (describing a festival, many months away):

$$
\begin{array}{llll}
i \text {-şammáá-n [...] ə } & n \text {-asáqqad } & n & \text { mjárdag. } \\
\text { 3-cook.IPFV-PL uh } & \text { GEN-to_make_hot } & \text { GEN } & \text { mjardag. }
\end{array}
$$

1 All Siwi data is from the author's fieldwork unless otherwise indicated. 
They cook ... uh, mjardag stew (made of bread and meat).

$\begin{array}{llll}\text { wó-k lázam itádəm nnúba } & \text { ge-y-čč-án. } \\ \text { DEM.M-2:M must people all } & \text { IRR-3-eat-PL. } \\ \text { This, all the people must eat. }\end{array}$

The same applies, naturally, to recognitional usages:

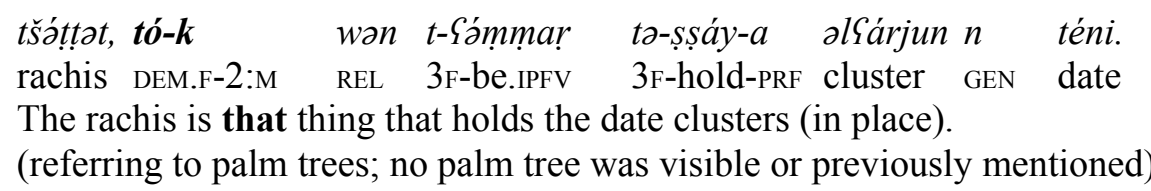

Conversely, items new to the discourse - notably including the topics of questions - are usually marked with the proximal demonstrative:

15 hánta wa i-támmma-n-as?

what? DEM.M 3-Say.IPFV-PL-3SG.DAT?

What do they call this/that?

16

$\begin{array}{ll}\text { táya } & \text { tšáttot. } \\ \text { DEM.F } & \text { rachis }\end{array}$

This is the rachis. (showing the parts of a bird trap; no previous mention.)

This discourse-oriented usage often overrides both spatial considerations:

hánta wáya wan annij $g$ assmá?
what? DEM.M REL up in sky
What is that up there in the sky?

and considerations of accessibility:

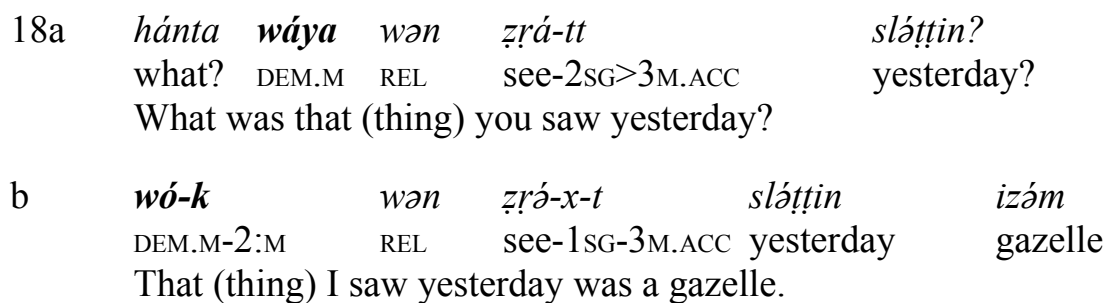

The proximal terms have an additional function of expressing contrastive alternatives: "one... the other..." is $w a \ldots w a \ldots$ This overrides spatial functions of the proximal-medial distinction, as in the following scenario: 
A and B are sitting in a room with four books on the desk, two of them green. A tells B to go get the green book. B goes and puts his hand on one of them, and says: wá? / wáya? [This one?] A replies:

19

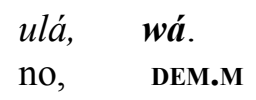

Purely exophoric usages of the demonstrative system are also found. The clearest contrast is between proximal/medial demonstratives (near the conversational dyad) on the one hand and distal (away from the conversational dyad) on the other, as in:

$$
\begin{array}{llll}
\boldsymbol{t} \boldsymbol{o}-\boldsymbol{k} & \text { isíwan, } & \boldsymbol{t} \text {-íh } & \text { ayármi } \\
\text { DEM.F-2:M } & \text { Siwa, } & \text { DEM.F-DIST } & \text { Aghurmi }
\end{array}
$$

This is Siwa (where the speaker is), that's Aghurmi (another village).

Spatial contrasts between the proximal and medial series are also attested - thus, from a video explaining how a bird trap works (both first mentions):

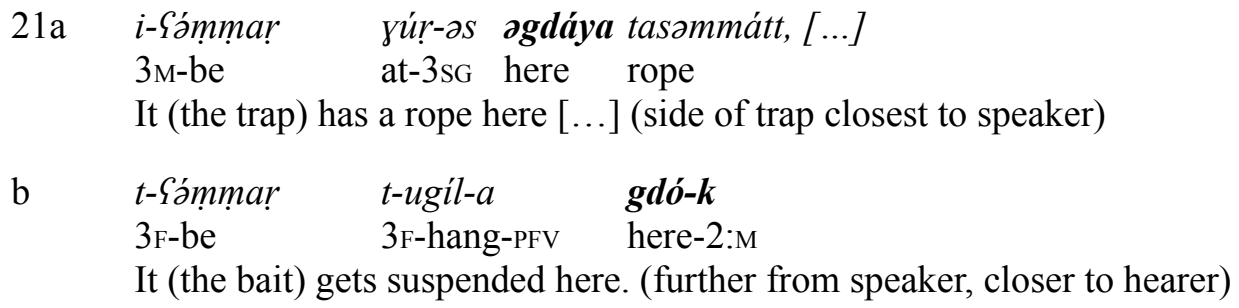

However, the spatial distinction appears to be the least important function of the latter, in that it is normally overridden by accessibility (as in the following example), information status (as in 17), and even contrastiveness (as in 19).

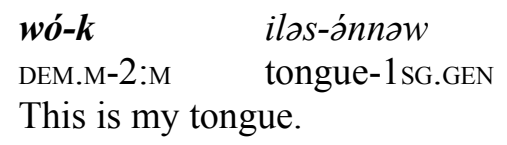

\section{Addressee agreement and documentation gaps}

The fact that in a typical elicitation situation the addressee is always the linguist is what has led to the omission of addressee agreement from previous descriptions of Siwi (LaOust 1931; Vycichl 2005), which give only M.SG addressee forms. There is reason to suspect a similar gap in other eastern Berber data. The closest relatives of Siwi, spoken in Libya, are the varieties of Sokna (SARNelli 1924), El-Fogaha (PARADISI 1963). The two articles cited are the only published source of textual data 
on these varieties, and it is not clear whether either is still spoken. Both, unusually for Berber but like Siwi, use a suffix $-k$ in non-proximal demonstratives (Table 2).

No textual examples of the demonstrative in question are available for El-Fogaha, so nothing can be said about its usage there. For Sokna, the demonstrative in question occurs three times in the surviving text corpus (all in text IV, SARnELll 1924:34), never in quoted speech, so there is no way to determine whether it shows addressee agreement. Two occurrences are in the context of a dialogue between a man and a king, both previously mentioned: "the man said to that king (iyisséltān udinak)... And he did not say to that man (imâr udinak) ...". The third is temporal: "at that time (déluqü*t eddinak) they brought the king his supper". In each case, its usage is anaphoric, like Siwi wok. If any speakers of either language remain, it would be very interesting to test their usage with non-masculine singular addressees.

Table 2: Demonstratives in Sokna and El-Fogaha

\begin{tabular}{|c|c|c|c|c|}
\hline & \multicolumn{2}{|l|}{ proximal } & \multicolumn{2}{|l|}{ distal } \\
\hline & Sokna & El-Fogaha & Sokna & El-Fogaha \\
\hline Pronominal: M.SG & $w \bar{a}$ & $w a$ & udînak & wenhák \\
\hline- F.SG & $t \bar{a}$ & $t a$ & eddînak & tenhák \\
\hline - M.PL & ummâ & $w i$ & ummadînak & wenhák \\
\hline - F.PL & $n t \hat{\imath}$ & $t i$ & ntidînak & tenhák \\
\hline Adnominal & eddâ & SG $d d a$, PL $d d i$ & (= pronominal $)$ & ddén \\
\hline Presentative: M.SG & $u k k \hat{a}$ & akkâ & & \\
\hline- F.SG & ukettâ & akettâ & & \\
\hline - M.PL & ukummî & & & akkên \\
\hline - F.PL & $u k u t t \hat{\imath}$ & & & akettên \\
\hline Locative & $d \bar{a}$ & & & denhâk \\
\hline
\end{tabular}


Another somewhat promising case is to be found in the closest Berber neighbour of Siwi, the variety of Awjila (PARADISI 1960). This variety is not at all closely related to Siwi, but shows some signs of contact convergence. It, too, has a demonstrative in $-k$, contrasting with at least three other demonstrative series - more than any other variety examined thus far - none of whose usage has been described in any detail, as the vague and overlapping labels below suggest:

Table 3: Demonstratives in Awjila

\begin{tabular}{|c|c|c|c|c|c|}
\hline & proximal & proximal & proximal & medial & distal \\
\hline Pronominal: M.SG & $w a ́$ & wāya & wék & & wîwan \\
\hline - F.SG & tá & tāya & ték & & tîwan \\
\hline - M.PL & & wîya & & & widânin \\
\hline - F.PL & & tîya & & & tidânin \\
\hline Adnominal: SG & $-e ́$ & $-a ́ y a$ & -ék & $-i d \bar{d} n$ & -íwan \\
\hline$-\mathrm{PL}$ & & $-\hat{\imath} y a$ & -îyek & & -idânīn \\
\hline Locative & dîla & & dîlak & & dilîwan \\
\hline Ablative & sîla & & sîlak & & diššŝîwān \\
\hline Manner adverb & & & tûdìk & & \\
\hline
\end{tabular}

As noted by van Putten (2013:125), Paradisi 1961 (the only published source for Awjila texts) provides two textual examples of the relevant demonstrative's usage, in a version of Aesop's fable of the Bundle of Sticks: "afterwards he told them: look, you are like these sticks (tgarīwin-îyek); if you gather yourselves together you will remain like these sticks (am tégarîwîn-îyāk)". The context indicates that the sticks were in the hearers' hands; the apparent usage of the demonstrative here for indicating proximity to the hearers is again in line with the function of Siwi wok, suggesting a common history. Both of these examples are in quoted speech with a plural addressee, suggesting that addressee agreement, if it exists at all in Awjila, is not obligatory. However, comparison with Siwi example 10 above shows that this is not conclusive, since each individual stick was close to an 
individual addressee, not to the group as a whole. In Awjila, too, the possibility of variable addressee agreement ought to be tested for in the event of further fieldwork.

\section{Conclusion}

The case of Siwi shows that the mapping of deixis onto person in person-oriented demonstrative systems can be iconically represented by the use of personal pronominal morphemes, leading to addressee agreement $-\mathrm{a}$ hitherto unrecognised form of deixis. In particular, addressee agreement is found both on listeneranchored spatial deictics and on listener-familiar anaphoric forms. While this phenomenon seems to be typologically unusual, the fact that linguists on the whole do not expect to find it and hence rarely look for it makes it likely that its frequency has been underestimated. Future documentation efforts, not only in Berber but also further afield, should test for this possibility.

\section{Abbreviations}

$\begin{array}{llll}\text { 2:M/F/PL agreement with the } & \text { IMP } & \text { imperative } \\ & \begin{array}{l}\text { masculine / feminine / } \\ \text { plural addressee }\end{array} & \text { IPFV } & \text { imperfective } \\ \text { ACC } & \text { accusative } & \text { IRR } & \text { irrealis } \\ \text { COMP } & \text { complementizer } & \text { M } & \text { masculine } \\ \text { DAT } & \text { dative } & \text { MOD } & \text { adnominal prefix } \\ \text { DEM } & \text { demonstrative } & \text { PL } & \text { plural } \\ \text { DIST } & \text { distal } & \text { PRF } & \text { perfect } \\ \text { F } & \text { feminine } & \text { PRSV } & \text { presentative } \\ \text { GEN } & \text { genitive } & \text { REL } & \text { relative } \\ & & \text { SG } & \text { singular }\end{array}$

\section{References}

Alberdi, JABIER (1995): The development of the Basque system of terms of address and the allocutive conjugation, in: Hualde, José I.; Lakarra, Joseba \& Trask, Robert L. (eds.), Towards a history of the Basque language. (Current Issues in Linguistic Theory 131). Amsterdam: John Benjamins, 275-293.

Anderson, Stephen R. \& Keenan, Edward (1985): Deixis. In: Shopen, Timothy (ed.), Language Typology and Syntactic Fieldwork, vol. 3. Cambridge: Cambridge University Press, 259308.

Antonov, Anton (2010): Verbal allocutivity in a crosslinguistic perspective. http:/www.academia.edu/ 1817520/Verbal_allocutivity_in_a_crosslinguistic_perspective (21 October, 2012).

Brugmann, Karl (1904): Die Demonstrativpronomina der indogermanischen Sprachen. (Abhandlungen der philologisch-historischen Klasse der Königl. Sächsischen Gesellschaft 
der Wissenschaften 22/6). Leipzig: Teubner.

Diessel, Holger (1999): Demonstratives: Form, Function, and Grammaticalization. (Typological Studies in Language 42). Amsterdam: John Benjamins.

Diessel, Holger (2011): Distance Contrasts in Demonstratives. In: Dryer, Matthew S. \& Haspelmath, MARTIN (eds.), The World Atlas of Language Structures Online. Max Planck Digital Library. http://wals.info/chapter/41 (24 September, 2012).

Greenberg, Joseph H. (1985): Some iconic relationships among place, time, and discourse deixis. In: Haiman, John (ed.), Iconicity in Syntax. (Typological Studies of Language 6). Amsterdam: John Benjamins.

Hayashi, Makoto \& Kyung-Eun Yoon (2006): A cross-linguistic exploration of demonstratives in interaction: with particular reference to the context of word-formulation trouble, in: Studies in Language 30(3), 485-540.

Imai, Shingo (2003): Spatial Deixis. Buffalo: State University of New York doctoral thesis.

Laoust, Émile (1931): Siwa. (Publications de l'Institut des Hautes-Études Marocaines 22). Paris: Ernest Leroux.

Mettouchi, Amina (2011): Demonstratifs et construction de la référence en kabyle. In: Metrouchi, Amina (ed.), "Parcours berbères » Mélanges offerts à Paulette Galand-Pernet et Lionel Galand pour leur 90e anniversaire. (Berber Studies 33). Köln: Rüdiger Köppe, 469-484.

Paradisi, Umberto (1960): Il berbero di Augila, Materiale lessicale, in: Rivista degli Studi Orientali XXXV, 157-177.

PARAdisi, Umberto. 1961. Testi berberi di Augila (Cirenaica). Annali dell'Istituto Universitario Orientale di Napoli X. 79-91.

Paradisi, Umberto (1963): Il linguaggio berbero di El-Fógăha (Fezzân), in: Istituto Orientale di Napoli XIII, 93-126.

Putten, Marijn van. 2013. A Grammar of Awjila Berber (Libya) Based on Umberto Paradisi's Material. Leiden: University of Leiden $\mathrm{PhD}$ thesis.

Sarneldi, Tommaso (1924): Il dialetto berbero di Sokna: Materiali lessicali, testi manoscritti in caratteri arabi, con trascrizione e traduzione. Supplemento all'Africa Italiana.

Souag, Lameen (2010): Grammatical Contact in the Sahara: Arabic, Berber, and Songhay in Tabelbala and Siwa. School of Oriental and African Studies, University of London doctoral thesis.

Vycichl, Werner (2005): Berberstudien; \&, A Sketch of Siwi Berber (Egypt). (Berber Studies 10). Köln: Rüdiger Köppe.

Watson, Janet, Bonnie Glover Stalls, Khalid al-Razihi \& Shelagh Weir. 2006b. Two Texts from Jabal Rāziḥ, North-west Yemen. In Lutz EdzARd \& JAN Retsö (eds.), Current Issues in the Analysis of Semitic Grammar and Lexicon II: Oslo-Göteborg Cooperation 4th-5th November 2005. (Abhandlungen für die Kunde des Morgenlandes LIX). Wiesbaden: Harrasowitz. 